\title{
Tumoural denervation of the nigrostriatal pathway
}

\author{
Martin Victor Añaños • Teresa Baringo • \\ Paola Lievano • Leticia De la Cueva • Pablo Navarro • \\ Estela Arroyo • Mario Gonzalez • Dolores Abos
}

Received: 7 August 2009 /Accepted: 28 August 2009 /Published online: 24 September 2009

(C) Springer-Verlag 2009

A 22-year-old woman, diagnosed 7 years ago with low-grade astrocytoma in the left mesencephalon, presented with an initial clinical picture of severe intention and resting tremor in the right limbs.

The tumour was treated with radiation therapy, and currently no signs of progression appear in the radiological control examinations, although the symptoms still persist and prevent the patient from carrying out daily activities.

The last radiological exam (A) showed a calcified tumour in the left thalamus and mesencephalon, without structural affectation in the basal ganglia, so a functional assessment of the nigrostriatal system through a combined study of presynaptic dopamine transporters and postsynaptic $\mathrm{D}_{2}$ receptors was performed [1].

The study performed with $\left[{ }^{123}\right.$ I]FP-CIT SPECT (B) shows absence of uptake in the left striatum and preserved uptake in the contralateral one. These findings suggest the existence of an interruption of the left nigrostriatal connections, with integrity of the right nigrostriatal pathway, consistent with the anatomical location of the tumour [2].

The study of $\mathrm{D}_{2}$ receptors with $\left[{ }^{123} \mathrm{I}\right] \mathrm{IBZM} \operatorname{SPECT}(\mathrm{C})$ demonstrates intense uptake of the radiotracer in the left striatum and normal uptake in the right $\mathrm{D}_{2}$ postsynaptic receptors.

M. V. Añaños $(\bowtie) \cdot$ T. Baringo $\cdot$ P. Lievano $\cdot$ L. De la Cueva $\cdot$

P. Navarro · E. Arroyo - M. Gonzalez - D. Abos

Department of Nuclear Medicine,

Hospital Universitario Miguel Servet,

P. Isabel la Católica 1-3.,

50009 Zaragoza, Spain

e-mail: martin-victor@hotmail.com
The discrepancy between the study of receptors and transporters can be explained by upregulation of the left postsynaptic $\mathrm{D}_{2}$ receptors $[3,4]$, secondary to denervation of the left nigrostriatal connections by the expansive process in the mesencephalon.
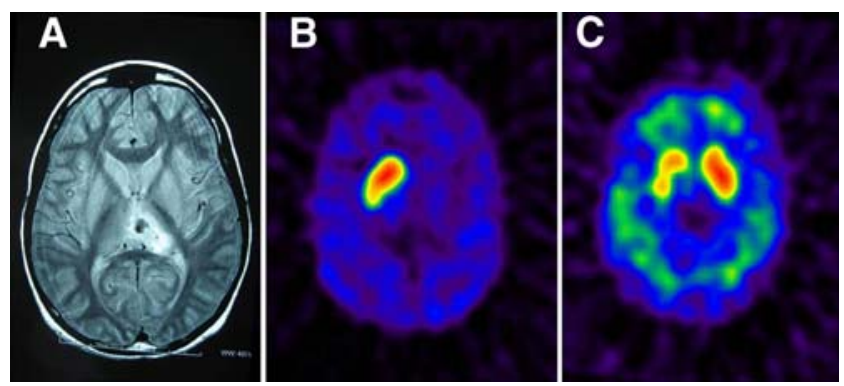

\section{References}

1. Koch W, Hamann C, Radau PE, Tatsch K. Does combined imaging of the pre- and postsynaptic dopaminergic system increase the diagnostic accuracy in the differential diagnosis of parkinsonism? Eur J Nucl Med Mol Imaging 2007;34(8):1265-73.

2. Ho BL, Lieu AS, Hsu CY. Hemiparkinsonism secondary to an infiltrative astrocytoma. Neurologist 2008;14(4):258-61.

3. Verstappen CC, Bloem BR, Haaxma CA, Oyen WJ, Horstink MW. Diagnostic value of asymmetric striatal D2 receptor upregulation in Parkinson's disease: an [123I]IBZM and [123I]FP-CIT SPECT study. Eur J Nucl Med Mol Imaging 2006;34(4):502-7.

4. Cai G, Wang HY, Friedman E. Increased dopamine receptor signaling and dopamine receptor-G protein coupling in denervated striatum. J Pharmacol Exp Ther 2002;302:1105-12. 